\title{
ECOLOGICAL AND GENETIC ADVANCES IN THE CULTIVATION OF TUBER SPP.
}

\author{
AVANCES ECOLÓGICOS Y GENÉTICOS EN EL CULTIVO DE TUBER SPP.
}

\author{
Alessandra Zambonelli*, Pamela Leonardi ${ }^{1}$, Mirco lotti² and lan Hall ${ }^{3}$
}

\begin{abstract}
'Department of Agricultural Science, Bologna University, viale Fanin 46, 40127 Bologna Italy. ${ }^{2}$ Department of Life, Health and Environmental Sciences, L'Aquila University, via Vetoio, Coppito 1, 67100 L'Aquila, Italy. ${ }^{3}$ Truffles and Mushrooms (Consulting) Ltd, P.O. Box 268, Dunedin 9054, New Zealand

*Corresponding author (alessandr.zambonelli@unibo.it)
\end{abstract}

\begin{abstract}
SUMMARY
Recent advances on the ecology and genetics of true truffles (Tuber spp.) are reported and their impact on truffle cultivation is discussed. New insights have been gained on truffle soil ecology and interrelationships of truffles with associated microorganisms in the soil. For instance, some bacteria seem to play a key role in truffle fruiting body formation and maturation. However, the most important advance in truffle genetics over the past 20 years has been the sequencing of the Tuber melanosporum genome and the discovery that truffles, like other Pezizalean fungi, are heterothallic. This finding has had a significant impact on research on truffles and many studies have been devoted to better understanding the distribution of the mating types in soil in natural and cultivated truffières. The characterization of the mating type idiomorphs of several Tuber species has led to the possibility of selecting mycelial strains for truffle cultivation in particular sites.
\end{abstract}

Index words: True truffles, ecology, genetics, cultivation.

\section{RESUMEN}

Avances recientes en la ecología y la genética de las trufas verdaderas (Tuber spp.) se reportan y se discute su impacto sobre el cultivo de la trufa. Nuevas perspectivas han surgido en la ecología del suelo de la trufa y las interrelaciones de las trufas con microorganismos asociados en el suelo. Por ejemplo, algunas bacterias parecen tener un papel clave en la formación del cuerpo fructífero de trufa y su maduración. Sin embargo, el avance más importante en la genética de la trufa en los últimos 20 años ha sido la secuenciación del genoma de Tuber melanosporum y el descubrimiento que la trufa, como otros hongos Pezizalean, es heterotólica. Este hallazgo ha tenido un impacto significativo en la investigación sobre trufas y muchos estudios se han dedicado a entender mejor la distribución de los tipos de apareamiento en el suelo en truffières naturales y cultivadas. La caracterización de los idiomorfos del tipo de apareamiento de varias especies Tuber ha conducido a la posibilidad de seleccionar cepas miceliales para el cultivo de trufa en sitios específicos.

Palabras clave: Trufas verdaderas, ecología, genética, cultivo.

\section{INTRODUCTION}

True truffles (Tuber spp.) are the most valuable of the edible ectomycorrhizal mushrooms. They are characterized by hypogeous fruiting bodies, many of which have evolved intense aromas for dispersing their sequestrate spores by animals (Trappe and Claridge, 2010). Their unique aromasmake these fungi unique in European cuisine.
The most economically important species of truffle, Tuber magnatum Pico (Italian white truffle), Tuber melanosporum Vittad. (Périgord black truffle), Tuber aestivum Vittad. (Summer truffle or Burgundy truffle) and Tuber borchii Vittad. (bianchetto truffle), naturally grow only in Europe, and Italy and France are the countries with the longest tradition of their consumption. The gastronomic interest in truffles and their economic value has stimulated researchers to find the most efficient methods for cultivating them. The first Italian and French attempts to cultivate truffles dates to the Renaissance. However, the first real success did not start until the early 1800s when Josef Talon in France developed a crude but effective method for cultivating the Périgord black truffle (Hall et al., 2007; Hall and Zambonelli, 2012).

Modern truffle cultivation began in the early 1970's when Italian and French researchers improved techniques to produce plants from seedlings or cuttings colonized by the target species of truffle (Zambonelli et al., 2015). Around the same time the first studies on Tuber ecology were being carried out with the aim of defining the ideal soil and climatic conditions suited to the various species of truffle (Delmas and Durand, 1971; Montacchini et al., 1977; Zambonelli and Di Munno, 1992). These studies established the basis for the explosion of truffle cultivation in France and Italy and soon after in Spain (Reyna and Garcia-Barreda, 2014). Beginning in the 1980s, Tuber cultivation was introduced into other European countries where truffles were not traditionally appreciated, and many non-European countries including Argentina, Australia, Chile, China, Israel, Morocco, New Zealand, South Africa, and USA also got involved (Berch and Bonito, 2014; Hall and Haslam, 2013; Wang, 2012; Reyna and Garcia Barreda, 2014; Zambonelli et al., 2015).

Since the turn of the century significant advances on Tuber genetics and molecular ecology were achieved with the contributions of researchers in several European countries and particularly the USA and Australia. Moreover, a suite of molecular approaches is now available to commercial 
nurseries and truffle growers either to check the quality of inoculated plants or to evaluate the status of natural and cultivated truffières (for a review see Parladé et al., 2016). In this review, we focus our attention on recent major advances on truffle ecology and our understanding of the genetics of the genus Tuber, which are likely to have a major bearing on their future cultivation.

\section{ECOLOGICAL STUDIES}

Most of the ecological studies carried out over the past 30 years have regarded the abiotic environment where the truffle lives, and the physical and soil chemical characteristics, and climate. Relatively few studies have paid attention to the flora, fauna and vegetation of the truffle producing areas (Zambonelli and Di Munno, 1992). This has been a mistake because truffles live in complex environments and intimate relationships with other soil organisms including other fungi, as well as bacteria and invertebrates which may influence the survival of truffle mycelium and its ability to colonize suitable host plants (Figure 1). These in turn may trigger fruiting or modify the organoleptic qualities of truffles.

Attention has been aimed at other ectomycorrhizal (ECM) fungi living on the same plants hosting the mycorrhizas of Tuber in cultivated and in natural truffières (De Miguel et al., 2014). The ECM fungi were generally assumed to compete with Tuber spp. in a sort of underground warfare aimed at mycorrhizal domination (Hall et al., 2007). This concept might well be visualized in a young truffle orchard where seedlings are (hopefully) only colonized by

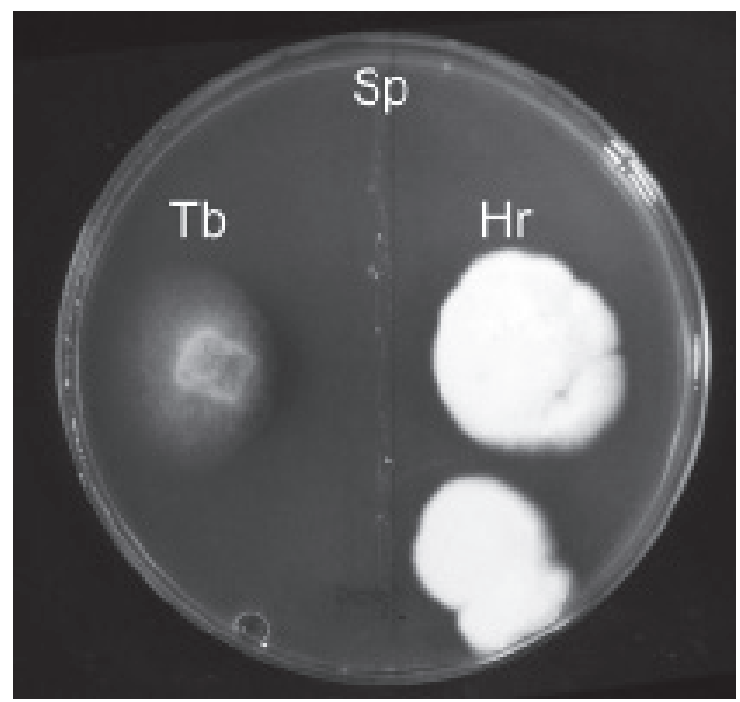

Figure 1. Effect on mycelial radial growth of the coinoculation of Tuber borchii (Tb) and Hebelona radicosum (Hs) with Staphylococcus pasturii (Sp). The bacterium strongly inhibits only the mycelial growth of $T$. borchii.
Tuber spp. but then quite quickly also became colonized by the native ECM fungi. In this situation only if the soil characteristics are suitable will the introduced Tuber species would be able to compete with other ECM fungi for space on the young roots.

When soil conditions are suitable to the truffle development, competition may occur between different Tuber species. For example, T. melanosporum was found to compete with Tuber brumale Vittad. in most of the countries where truffle cultivation has been introduced (Berch and Bonito, 2014; Guerin-Laguette et al., 2013; Linde and Selmes, 2012; Reyna, 2012; Souzart, 2011). In Israel and southern Italy the most competitive truffle with $T$. melanosporum seems to be T. aestivum (Belfiori et al., 2012; Bencivenga et al., 1992; Turgeman et al., 2012). Similarly, in New Zealand problems of competition have also been found between $T$. borchii and Tuber dryophilum Tul. \& C. Tul. and between T. melanosporum and Tuber maculatum Vittad. (GuerinLaguette et al., 2013; Hall, personal communication; Hall et al., 2007). The problems of Tuber spp. contamination in cultivated truffières has been much more serious when the origin of these contaminations has been the nursery.

There is the risk of introducing unwanted Tuber species which may be invasive and may replace native or more valuable European truffle species. For instance, the Chinese black truffle, Tuber indicum Cooke \& Massee, has already been found to contaminate plants inoculated with $T$. melanosporum in Italy (Murat et al., 2008). Although the Chinese species Tuber sinoestivum J. P. Zhang \& P.G. Liu (Zhang et al., 2012) has not yet been found to contaminate T. aestivum inoculated plants in Europe, there is the ever present risk that this species will find its way onto European plants either through the accidental or deliberate mixing of its spores with $T$. aestivum in inocula (Zambonelli et al., 2012). To reduce the risks of having contaminated inocula used to produce Tuber mycorrhized plants, truffles can be screened and incorrect species removed prior to the production of inocula. Legislation on the certification of mycorrhized plants has also been applied in some countries, but is not universal in Europe (Andrés-Alpuente et al., 2014; Murat, 2015).

The situation in natural truffières is quite different from plantations. In a mature forest, a root system is colonized by different ECM fungi which establish a dynamic equilibrium and are dependent on the soil's biotic and abiotic conditions. Distinct species of Tuber can share the same soil niches or occupy distinct soil patches. For example, Leonardi et al. (2013) found ectomycorrhizas of different Tuber species close to T. magnatum ascomata whereas T. borchii and T. dryophilum were never found to colonize the same patch of soil (lotti et al., 2010). 
At the end of the $20^{\text {th }}$ century the ECM fungal communities in truffières were studied using morphological techniques (De Miguel et al., 2014). In these studies, root samples were first examined under a stereomicroscope and their external features described. A small portion of the mantle was then observed under a light or interference microscope to examine the anatomical features and the characteristics of the external hyphal elements (hyphae, rhizomorphs and cystidia) (Agerer, 1987-2012). Based on their characteristics the examined mycorrhizas were assigned to different morphotypes, and occasionally it was possible to identify the fungal partner. Thanks to PCRbased molecular techniques for fungal identification (genotyping) (Peay et al., 2008) understanding of the fungal communities of truffières has increased considerably in recent years with the internal transcribed spacers (ITS) of rDNA, the PCR target region for the taxonomic identification of ECM fungi.

The comparison of the fungal ITS sequences obtained from a morphotype against those deposited in International Nucleotide Sequence Database (INSD: GenBank, EMBL, and DDBJ) has allowed us to identify the taxa of the symbiotic fungi at genus or even species level or, at worst, to assign it to one of the main ECM lineages (Telephoroid, Sebacinoid, Agaricoid, etc.) (Zambonelli et al., 2012). For example, molecular analyses have made it possible to identify the AD morphotype (Giraud, 1979), as Trichophaea woolhopeia (Cooke \& W. Phillips) Boud. which is one of the most common ECM fungi in Italian, French and Spanish truffières (Baciarelli Falini et al., 2006; De Miguel et al., 2014). It has also been possible to study and compare the fungal communities in productive and non-productive truffières (Leonardi et al., 2013; Napoli et al., 2010).

In general, where T. melanosporum, T. aestivum, T. borchii and T. macrosporum fruiting bodies are found their mycorrhizas are abundant (Benucci et al., 2011, 2014; lotti et al., 2010; Napoli, 2010). Moreover, the presence of T. melanosporum reduces the fungal diversity inside the brûlè (burnt area) (Napoli et al., 2010), which is the area of soil around the host plant generally devoid of vegetation where truffles are formed (Pacioni, 1991). In contrast, in natural productive $T$. magnatum truffières mycorrhizas are absent (Leonardi et al., 2013) or quite rare (Bertini et al., 2006; Murat et al., 2005). This has made it very difficult to study this truffle in its natural environment.

Recently, methods have been developed to identify and quantify T. magnatum mycelium in the soil by lotti et al. (2012). Tuber magnatum mycelium was found to form large patches in productive areas (Zampieri et al., 2010), and using real time PCR, it was possible to determine its spatiotemporal dynamics (lotti et al., 2014). It was found that $T$. magnatum mycelium is particularly abundant and widespread in spring and tends to concentrate in the productive areas during fruiting (autumn) (lotti et al., 2014). Using this technique it was possible to assess the effects of cultural practices on T. magnatum and suggest methods for its future cultivation (Salerni et al., 2014). The same technique was also applied to detect and quantify T. melanosporum and T. aestivum mycelium in the soil (Gryndler et al., 2013b; Parladè et al., 2013). The growth rate of development of T. aestivum mycelium in the soil was established (Gryndler et al., 2015), moreover the presence of Tuber aestivum mycelium in herbaceous plants was found inside the brûlè (Gryndler et al., 2014) confirming previous results obtained by Plattner and Hall (1995) 20 years earlier for T. melanosporum using immunological techniques.

Interesting insights were obtained recently by metagenomics and metaproteomics, coupled with next generation sequencing, where the whole microbial community of an environmental sample is examined after the extraction of total DNA or RNA. These studies can be used not only to determine fungal diversity but also the bacterial diversity in soil, roots or ascomata and to elucidate their metabolic pathways (Benucci and Bonito, 2016; Zamperi et al., 2016). That is particularly important because the presence of certain bacterial species may drive the composition of fungal communities favoring the development of some ECM species. For example, it was found that the ubiquitous bacterium, Staphylococcus pasteurii, completely inhibited the development of T. borchii and Suillellus luridus (Schae ff.) Murrill (=Boletus luridus) in vitro but had no effect on Hebeloma radicosum (Bull.) Ricken (Barbieri et al., 2005b), which as with other Hebeloma spp., is considered a competitor of T. borchii in the field (Zambonelli and lotti, 2001).

An extensive bacterial and fungal diversity has been found inside truffle ascomata (Barbieri et al., 2005a; Barbieri et al., 2007; Benucci and Bonito, 2016; Gryndler et al., 2013a; Pacioni et al., 2007). Some of these can rot truffles (Figure 2a, b, c and d) and can result in significant losses particularly in Australian truffières (Eslick, 2012, 2013). Some of the bacterial pathogens have defied cultivation which has limited our understanding of how they might be controlled. Other uncultivable bacteria seem to be selected from the soil communities during the early stage of truffle formation and may be beneficial to truffle growth. The genus Bradyrhizobium seems to be specific to the ascomata of Tuber spp. (Antony-Babu et al., 2014; Barbieri et al., 2005a; Barbieri et al., 2007; Benucci and Bonito, 2016; Gryndler et al., 2013a). Bacteria closely related to Bradyrhizobium spp. and bacteria belonging to Epsilonproteobacteria and Firmicutes subdivisions may be able to fix nitrogeninside T. magnatum ascomata, and perhaps could have a key role in fruiting body nutrition (Barbieri et 
al., 2010). Interestingly, the $\beta$-Proteobacteria found in $T$. borchii fruiting bodies could produce thiophene volatiles which are major contributors to the human-sensed aroma of T. borchii (Splivallo and Ebeler, 2015) by biotransformation of nonvolatile precursor(s) into volatile compounds (Spivallo et al., 2015).

Recently viruses have also been found inside Tuber excavatum Vittad. and T. aestivum (Stielow and Menzel, 2010; Stielow et al., 2011a, 2011b, 2012). Infected truffles are apparently symptomless, but it is still not clear whether the presence of mycoviruses in truffles affects fruiting body formation, mycelium growth or its ability to form mycorrhizas. Recently, a virus belonging to the genus Endornavirus was found inside T. magnatum fruiting bodies and reported to produce external brown spots (Ratti et al., 2016). If confirmed, this species would be the first evidence of a symptomatic mycovirus in a truffle causing severe reduction of economic value (Figure $2 \mathrm{e}$ ).

Another important ecological aspect which could have an impact on truffle cultivation is the role of animals (e.g. mammals, insects) on spore dispersal and germination. Recent studies showed that inoculating plants with T. aestivum spores digested by a pig, increased their ability to in- fect Quercus robur L. plants under greenhouse conditions (Piattoni et al., 2014). These results indicate that we should reconsider the importance of animals, such as wild boars in truffle cultivation (Salerni et al., 2013).

\section{GENETIC ADVANCES AND THE FUTURE}

Over the past 20 years numerous genetic studies have been carried out on truffles. These were aimed at understanding the genetic mechanisms which regulate mycorrhizal formation (Polidori et al., 2002), the formation and maturation of the fruiting bodies (Abbá et al., 2007; Zeppa et al., 2002), the origin and evolution of truffles (O'Donnell et al., 1997; Percurdani et al., 1999; see Bonito and Smith, 2016 for a review) and population genetics (Bertault et al., 2001 ; see the book by Zambonelli et al., 2016). The genome sequencing of T. melanosporum has opened new frontiers in the study of truffle genetics which has led to a better understanding of truffle cultivation (Martin et al., 2010). For example, it has been confirmed that Minter's 1985 observation (in Hall et al., 2010) that truffles have a sexual life cycle is correct and that it is also heterothallic i.e., fruiting body formation requires two different strains of different mating type to meet (Paolocci et al., 2006). The two idiomorphs of the mating types, MAT1-1-1 and MAT12-1, were
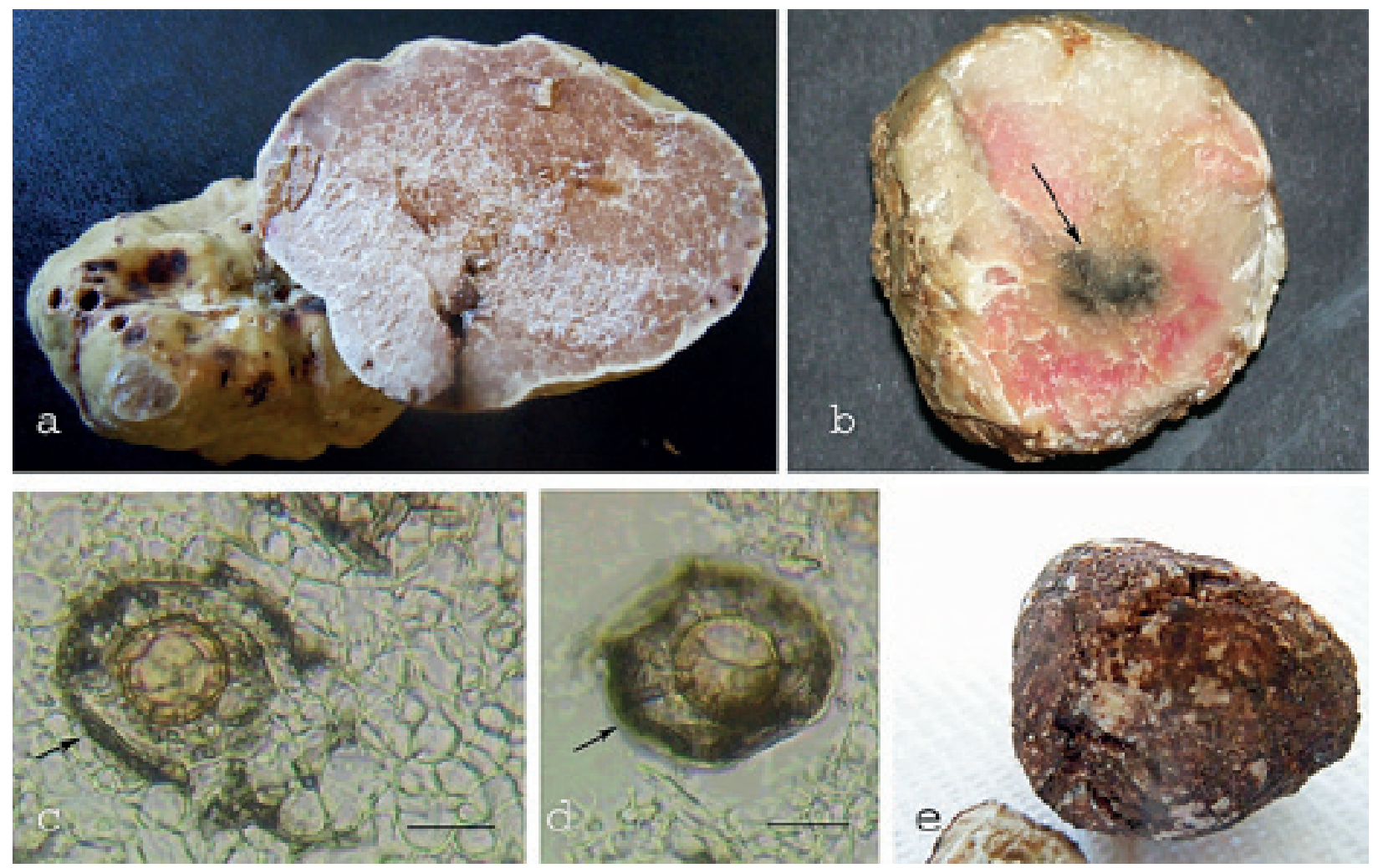

Figure 2. Tuber magnatum ascomata: a) healthy, b) affected by a bacterial and a central fungal infection (the arrow indicates the fungal infection), $\mathrm{c}$ and d) microscopic observations of the fungal infection of fig. $2 \mathrm{~b}$. The arrows indicate the hyphae of the invasive fungus (bars $=20 \mu \mathrm{m}$ ), e) affected by a mycovirus showing an anomalous brown peridium. 
characterized in several Tuber species (T. melanosporum, T. indicum and T. borchii) and specific primers to amplify them were designed (Belfiori et al., 2013, 2016; Rubini et al., 2011b).

Once we were aware that truffles had a sexual life cycle, inoculating plants for commercial use with mycelial cultures was deemed too risky. This is because pure cultures of mycelia are isolated from the gleba of fruiting bodies that is composed solely from maternal hyphae and hence only the maternal mating type. However, now that we are able to identify the mating type genes of Tuber mycelia, we can select strains of both mating types for inoculation purposes (Zambonelli et al., 2015). Recently the first truffles were harvested from trees inoculated with mycelial cultures carrying different strains of $T$. borchii demonstrating that in the future it will be possible to use this technique on a commercial scale (lotti et al., 2016). Mycelial inoculation offers numerous advantages such as the possibility to completely exclude contamination from other Tuber species in the inoculum, which, as discussed in the previous paragraphs, may create competition in the field. Moreover, in the future it may be possible to select the fungal strains used based on their genetic characteristics such as suitability to a specific set of ecological conditions.

After the discovery of the heterothallic nature of truffles, studies were carried out to better understand the distribution of the mating type in natural and cultivated truffières. In Australia, where T. melanosporum was introduced by cultivation, the scarce productivity of some truffières was attributed to low genetic diversity or to the absence of both mating types (Linde and Selmes, 2012). The results obtained showed that both the mating types were in fact present in the truffière, even if not always on the same plant. Instead, the major problem was confirmed to be the contamination of the plants with T. brumale at planting time. Surprisingly, like in productive Italian and French truffières, the two mating types were distributed in different patches inside the truffières (Murat et al., 2013; Rubini et al., 2011a). This now poses the question as to how the two mating types meet allowing fertilization and fruiting body production. Current theory suggests that mitospores are involved in fertilization (lotti et al., 2016) after mitotic spore mats of truffle species have been described (Urban et al., 2004; Healy et al., 2013), but Le Tacon et al. (2016) warned that this issue remains to be resolved.

\section{CONCLUSIONS}

Undoubtedly the major item of expenditure on edible mycorrhizal mushroom research over the past decade in Europe has been the sequencing of the Tuber genome, the discovery of the heterothallic nature of Tuber, the existen- ce of mating types and idiomorphs characterized, and their distribution in natural and cultivated truffières. From this, it has been demonstrated that mycelial strains carrying the mating types can be used to inoculate plants and produce truffles opening the use of this technique for the production of mycorrhized plants for truffle cultivation.

Advances in soil molecular ecology have given important insights into truffle biology and ecology offering a better understanding of the interrelationships between truffles and associated soil organisms. Some microbial groups could have a crucial role in mycorrhizal formation and the maturation of fruiting bodies suggesting possible ways microbiota might be exploited to improve truffle cultivation.

There remain huge gaps in our understanding of truffle biology. For example, it is still not known how or where the mating strains get together, and whether mitospores are involved in this process. The roles of bacteria in truffle ecology is still not clear either. The lack of funds for basic truffle research and studies to improve truffle yields is a major barrier to bridging this gap. For example, in the 1970s and 1980s various organic mixes were touted as truffle stimulants, whereas they reduced the number and weight of truffles from producing trees. Other products are now also being applied in truffle producing countries with little or no statistical data to back up claims that they stimulate truffle production. Indeed, in some instances productive truffières have ceased producing truffles following the application of such "fertilizers". In the absence of specialists investigating these new products it is left for the market or consumer rights legislation to decide the efficacy or otherwise of such products.

\section{BILIOGRAPHY}

Abbá S., R. Balestrini, A. Benedetto, H. Rottensteiner, J. R. De Lucas and P. Bonfante (2007) The role of the glyoxylate cycle in the symbiotic fungus Tuber borchii: expression analysis and subcellular localization. Current Genetics 52:159-170.

Agerer R. (1987-2012) Colour Atlas of Ectomycorrhizae. 1st-15th Volumes. Einhorn-Verlag + Druck GmbH, Schwäbisch Gmünd, Germany.

Andrés-Alpuente A., S. Sánchez, M. Martín, A. J. Aguirre and J. J. Barriuso (2014) Comparative analysis of different methods for evaluating quality of Quercusilex seedlings with Tuber melanosporum. Mycorrhiza 24:29-37.

Antony-Babu S., A. Deveau, J. D. Van Nostrand, J. Zhou, F. Le Tacon, C. Robin, P. Frey-Klett and S. Uroz (2014) Black truffle-associated bacterial communities during the development and maturation of Tuber melanosporum ascocarps and putative functional roles. Environmental Microbiology 16:2837-2847.

Baciarelli-Falini L., A. Rubini, C. Riccioni and F. Paolocci (2006) Morphological and molecular analyses of ectomycorrhizal diversity in a man-made Tuber melanosporum plantation: description of novel truffle-like morphotypes. Mycorrhiza 16:475-484.

Barbieri E., L. Bertini, I. Rossi, P. Ceccaroli, R. Saltarelli, C. Guidi, A. Zambonelli and V. Stocchi (2005a) New evidence for bacterial diversity in the ascoma of the ectomycorrhizal fungus Tuber borchii. FEMS Microbiology Letters 247:23-35. 
Barbieri E., P. Ceccaroli, R. Saltarelli, C. Guidi, L. Potenza, M. Basaglia, F. Fontana, E. Baldan, S. Casella, O. Ryahi, A. Zambonelli and V. Stocchi (2010) New evidence for nitrogen fixation within the Italian white truffle Tuber magnatum. Fungal Biology 114:936-942.

Barbieri E., A. M. Gioacchini, A. Zambonelli, L. Bertini and V. Stocchi (2005b) Determination of microbial volatile organic compounds from Staphylococcus pasteuri against Tuber borchii using solidphase microextraction and gas chromatography/ion trap mass spectrometry. Rapid Communications in Mass Spectrometry 19:3411-3415.

Barbieri E., C. Guidi, J. Bertaux, P. Frey-Klett, J. Garbaye, P. Ceccaroli, R. Saltarelli, A. Zambonelli and V. Stocchi (2007) Occurrence and diversity of bacterial communities in Tuber magnatum during truffle maturation. Environmental Microbiology 9:2234-2246.

Belfiori B., C. Riccioni, F. Paolocci and A. Rubini (2016) Characterization of the reproductive mode and life cycle of the whitish truffle T. borchii. Mycorrhiza 26:515-527.

Belfiori B., C. Riccioni, F. Paolocci and A. Rubini (2013) Mating type locus of Chinese black truffles reveals heterothallism and the presence of cryptic species within the Tuber indicum species complex. PLoS One 8:e82353.

Belfiori B., C. Riccioni, S. Tempesta, M. Pasqualetti, F. Paolocci and A. Rubini (2012) Comparison of ectomycorrhizal communities in natural and cultivated Tuber melanosporum truffle grounds. FEMS Microbiology Ecology 81:547-561.

Bencivenga M., D. Donnini and G. Di Massimo (1992) Analisi delle micorrize in una tartufaia coltivata di Tuber melanosporum undici anni dopol'impianto. Micologia e Vegetazione Mediterranea 7:159-171.

Benucci G. M. and G. M. Bonito (2016) The truffle microbiome: species and geography effects on bacteria associated with fruiting bodies of hypogeous pezizales. Microbial Ecology 72:4-8.

Benucci G. M. N., L. Raggi, E. Albertini, A. G. Csorbai and D. Donnini (2014) Assessment of ectomycorrhizal biodiversity in Tuber macrosporum productive sites. Mycorrhiza 24:281-292.

Benucci G. M. N., L. Raggi, E. Albertini, T. Grebenc, M. Bencivenga, M. Falcinelli and G. Di Massimo (2011) Ectomycorrhizal communities in a productive Tuber aestivum Vittad. orchard: composition, host influence and species replacement. FEMS Microbiology Ecology $76: 170-184$.

Berch S. M. and G. Bonito (2014) Cultivation of mediterranean species of Tuber (Tuberaceae) in British Columbia, Canada. Mycorrhiza 24:473-479. doi:10.1007/s00572-014-0562-y

Bertault G., F. Rousset, D. Fernandez, A. Berthomieu, M. E. Hochberg, G. Callot and M. Raymond (2001) Population genetics and dynamics of the black truffle in a man-made truffle field. Heredity 86:451-458.

Bertini L., I. Rossi, A. Zambonelli, A. Amicucci, A. Sacchi, M. Cecchini, G. Gregori and V. Stocchi (2006) Molecular identification of Tuber magnatum ectomycorrhizas in the field. Microbiological Research 161:59-64.

Bonito G. M. and M. E. Smith (2016) General systematic position of the truffles: evolutionary theories. In: True Truffle (Tuber spp.) in the World. Soil Ecology, Systematics and Biochemistry. Volume 47. A. Zambonelli, M. lotti and C. Murat (eds.). Springer International Publishing. Switzerland. pp:3-18.

De Miguel A. M., B. Águeda B., S. Sánchez and J. Parladé (2014) Ectomycorrhizal fungus diversity and community structure with natural and cultivated truffle hosts: applying lessons learned to future truffle culture. Mycorrhiza 24:S5-S18

Delmas J. and J. H. Durand (1971) Écologie truffière. Caractères pédologiques et agronomiques des sols trufficoles français. In: 1er Congrès International de la Trufficulture. 7-8th Mai 1971. Souillac, France. B. Fassi (ed.). Fédération Nationale des Producteurs de Truffes. pp:47-59.

Eslick H. (2012) Identifying the Cause of Rot in Black Truffles and Management Control Options. Industry Report. RIRDC Publication No. 12//005. Australian Government: Rural Industries Research and Development Corporation. Australia. $46 \mathrm{p}$

Eslick H. (2013) Identification and Management of the Agent Causing Rot in Black Truffles. Part 2. Industry Report. RIRDC Publication No. 13/111. Australian Govern-ment: Rural Industries Research and Development Corporation. 36p.

Giraud M. (1979) Etude comparative des mycorhizes d'arbres producteurs de truffes ou non en zone truffière. Graduation dissertation, Ecole Nationale Supérieure Agronomique 1 de Rennes, and Institut National de la recherche Agronomique, ClermontFerrand, France.
Gryndler M., O. Beskid, H. Hršelová, P. Bukovská, M. Hujslová, H. Gryndlerová, T. Konvalinková, A. Schnepf, L. Sochorová and J. Jansa (2015) Mutabilis in mutabili: spatiotemporal dynamics of a truffle colony in soil. Soil Biology \& Biochemistry 90:62-70.

Gryndler M., L. Černá, P. Bukovská, H. Hršelová and J. Jansa (2014) Tuber aestivum association with non-host roots. Mycorrhiza 24:603-610.

Gryndler M., L. Soukupová, H. Hršelová, H. Gryndlerová, J. Borovicka, E. Streiblová and J. Jansa (2013a) A quest for indigenous truffle helper prokaryotes. Environmental Microbiology Reports 5:346-352

Gryndler M., J. Trilčová, H. Hršelová, E. Streiblová, H. Gryndlerová and J. Jansa (2013b) Tuber aestivum Vittad. mycelium quantified: advantages and limitations of a qPCR approach. Mycorrhiza 23:341-348.

Guerin-Laguette A., N. Cummings, N. Hesom-Williams, R. Butler and Y. Wang (2013) Mycorrhiza analyses in New Zealand truffières reveal frequent but variable persistence of Tuber melanosporum in co-existence with other truffle species. Mycorrhiza 23:87-98.

Hall I. R., Brown G. and A. Zambonelli (2007) Taming the Truffle. The History, Lore, and Science of the Ultimate Mushroom. Timber Press, Portland, OR. 303 p.

Hall I. R. and W. Haslam (2012) Truffle cultivation in the Southern Hemisphere. In: Edible Ectomycorrhizal Mushrooms. Current Knowledge and Future Prospects. A. Zambonelli and G. M. Bonito (eds.). Springer-Verlag Berlin, Alemania. pp:191-208

Hall I. R. and A. Zambonelli A. (2012) Laying the foundations. In: Edible Ectomycorrhizal Mushrooms. Current Knowledge and Future Prospects. A. Zambonelli and G. M. Bonito (eds.). SpringerVerlag Berlin, Alemania. pp:3-16.

Hall I. R., A. Zambonelli and D. Minter (2010) Sex, croziers, truffles and variation. Österreichische Zeitschrift für Pilzkunde 19:191-199.

Healy R. A., M. E. Smith, G. M. Bonito, D. H. Pfister, Z. W. Ge, G. G. Guevara, G. Williams, K. Stafford, L. Kumar, T. Lee, C. Hobart, J. Trappe, R. Vilgalys and D. J. Mclaughlin (2013) High diversity and widespread occurrence of mitotic spore mats in ectomycorrhizal Pezizales. Molecular Ecology 22:1717-1732.

Iotti M., E. Lancellotti, I. R. Hall and A. Zambonelli (2010) The ectomycorrhizal community in natural Tuber borchii grounds. FEMS Microbiology Ecology 72:250-260

Iotti M., M. Leonardi, E. Lancellotti, E. Salerni, M. Oddis, P. Leonardi, C. Perini, G. Pacioni and A. Zambonelli (2014) Spatio-temporal dynamic of Tuber magnatum mycelium in natural truffle grounds. PloS One 9: e115921

Iotti M., M. Leonardi, M. Oddis, E. Salerni, E. Baraldi and A. Zambonelli (2012) Development and validation of a real-time PCR assay for detection and quantification of Tuber magnatum in soil. BMC Microbiology 12:93. doi: 10.1186/1471-2180-12-93.

Iotti M., F. Piattoni, P. Leonardi, I. R. Hall and A. Zambonelli (2016) First evidence for truffle production from plants inoculated with mycelial pure cultures. Mycorrhiza 26:793-798. doi:10.1007/s00572016-0703-6

Le Tacon F., R. Rubini, C. Murat, C. Riccioni, C. Robin, B. Belfiori, B. Zeller, H. De la Varga, E. Akroume, A. Deveau, F. Martin and F. Paolocci (2016) Certainties and uncertainties about the life cycle of the perigord black truffle (Tuber melanosporum Vittad.). Annals of Forest Science 73:105-117

Leonardi M., M. Iotti, M. Oddis, G. Lalli, G. Pacioni, P. Leonardi, S. Maccherini, C. Perini, E. Salerni and A. Zambonelli(2013) Assessment of ectomycorrhizal fungal communities in the natural habitats of Tuber magnatum Ascomycota (Pezizales). Mycorrhiza 23:349-358.

Linde C. C. and H. Selmes (2012) Genetic diversity and mating type distribution of Tuber melanosporum and their significance to truffle cultivation in artificially planted truffières in Australia. Applied and Environmental Microbiology 78:6534-6539.

Martin F., A. Kohler, C. Murat, R. Balestrini, P. M. Coutinho, O. Jaillon, B. Montanini, E. Morin, B. Noel, R. Percudani, B. Porcel, A. Rubini,A. Amicucci, J. Amselem, V. Anthouard, S. Arcioni, F. Artiguenave, J. M. Aury, P. Ballario, Bolchi A., Brenna A., Brun A., Buée M., Cantarel B., Chevalier G., Couloux A., Da Silva C., Denoeud F., Duplessis S., Ghignone S., Hilselberger B., lotti M., Mello M., Miranda M., Pacioni G., Quesneville H., Riccioni C., Ruotolo R., Splivallo R., Stocchi V., Tisserant E., Viscomi A.R., Zambonelli A., Zampieri E., Henrissat B., Lebrun M.H., Paolocci F., Bonfante P., Ottonello S. and P. Wincker (2010) Périgord black truffle genome uncovers evolutionary origins and mechanisms of symbiosis. Nature 464:1033-1038.

Montacchini F., G. Lo Bue and R. Caramiello (1977) Studi sull'ecologia del 
Tuber melanosporum. III. Fenomeni di inibizione nell'ambiente naturale nell'Italia centrale. Allionia 22:87-104.

Murat C., A. Vizzini, P. Bonfante and A. Mello (2005) Morphological and molecular typing of the below-groundfungal community in a natural Tuber magnatum truffle-ground. FEMS Microbiology Letters 245:307-313.

Murat C. (2015) Forty years of inoculating seedlings with truffle fungi: past and future perspectives. Mycorrhiza 25:77-81. doi:10.1007/s00572-014-0593-4

Murat C., A. Rubini, C. Riccioni, H. De la Varga, E. Akroume, B. Belfiori, M. Guaragno, F. Le Tacon, C. Robin, F. Halkett, F. Martin and F. Paolocci (2013) Fine-scale spatial genetic structure of the black truffle (Tuber melanosporum) investigated with neutral microsatellites and functional mating type genes. New Phytologist 199:176-187.

Murat C., E. Zampieri, A. Vizzini and P. Bonfante (2008) Is the Perigord black truffle threatened by an invasive species? We dreaded it and it has happened!. New Phytologist 178:699-702.

Napoli C., A. Mello, A. Borra, A. Vizzini, P. Sourzat and P. Bonfante (2010) Tuber melanosporum, when dominant, affects fungal dynamics in truffle grounds. New Phytologist 185:237-247.

O'Donnell K., E. Cigelnik, N. S. Weber and J. M. Trappe (1997) Phylogenetic relationships among ascomycetous truffles and the true and false morels inferred from $18 \mathrm{~S}$ and $28 \mathrm{~S}$ ribosomal DNA sequence analysis. Mycologia 89:48-65.

Pacioni G. (1991) Effects of Tuber metabolites on the rhizospheric environment. Mycological Research 95:1355-1358.

Pacioni G., M. Leonardi, P. Aimola, A. M. Ragnelli, A. Rubini and F. Paolocci (2007) Isolation and characterization of some mycelia inhabiting Tuber ascomata. Mycological Research 111:1450-1460.

Paolocci F., A. Rubini, C. Riccioni and S. Arcioni (2006) Reevaluation of the life cycle of Tuber magnatum. Applied and Environmental Microbiology 72:2390-2393.

Parladé P., H. De la Varga and J. Pera (2016) Tools to trace truffles in soil. In: True Truffle (Tuber spp.) in the World. Soil Ecology, Systematics and Biochemistry. A. Zambonelli, M. Iotti and C. Murat (eds.). Springer. Switzerland. pp:249-266.

Parladé P., H. De la Varga, A. M. De Miguel, R. Sáez and J. Pera (2013) Quantification of extraradical mycelium of Tuber melanosporum in soils from truffle orchards in northern Spain. Mycorrhiza 23:99106. doi: 10.1007/s00572-012-0454-y.

Peay K. G., P. G. Kennedy and T. D. Bruns (2008) Fungal community ecology: a hybrid beast with a molecular master. BioScience 58:799-810.

Percudani R., A. Trevisi, A. Zambonelli and S. Ottonello (1999) Molecular phylogeny of truffles (Pezizales: Terfeziaceae, Tuberaceae) derived from nuclear rDNA sequence analysis. Molecular Phylogenetics and Evolution 13:169-180.

Piattoni F., A. Amicucci, M. Iotti, F. Ori, V. Stocchi and A. Zambonelli (2014) Viability and morphology of Tuber aestivum spores after passage through the gut of Sus scrofa. Fungal Ecology 9:52-60.

Plattner I. and I. R. Hall (1995) Parasitism of non-host plants by the mycorrhizal fungus Tuber melanosporum. Mycological Research 99:1367-1370.

Polidori E., D. Agostini, S. Zeppa, L. Potenza, F. Palma, D. Sisti and V. Stocchi (2002) Identification of differentially expressed cDNA clones in Tilia platyphillos-Tuber borchii ectomycorrhizae using a differential screening approach. Molecular Genetics and Genomics 266:858-864

Ratti C., M. lotti, A. Zambonelli and F. Terlizzi (2016) Mycoviruses infecting true truffles. In: True Truffle (Tuber spp.) in the World. Soil Ecology, Systematics and Biochemistry. A. Zambonelli, M. lotti and C. Murat (eds.). Springer 47:333-349.

Reyna S. (2012) Truficultura: fundamentos y técnicas, 2nd edn. Ed. Mundi-Prensa, Madrid. 720 p.

Reyna S. and S. Garcia-Barreda (2014) Black Truffle cultivation: a global reality. Forest Systems 23:317-328

Rubini A., B. Belfiori, C. Riccioni, S. Arcioni, F. Martin and F. Paolocci (2011a) Tuber melanosporum: mating type distribution in a natural plantation and dynamics of strains of different mating types on the roots of nursery-inoculated host plants. New Phytologist 189:723-735

Rubini A., B. Belfiori, C. Riccioni, E. Tisserant, S. Arcioni, F. Martin and F. Paolocci (2011b) Isolation and characterization of MAT genes in the symbiotic ascomycete Tuber melanosporum. New Phytologist
189:710-722

Salerni E., L. Gardin, F. Baglioni and C. Perini (2013) Effects of wild boar grazing on the yield of summer truffle (Tuscany, Italy). Acta Mycologica 48:73-80

Salerni E., M. Iotti, P. Leonardi, L. Gardin, N. D'Aguanno, C. Perini, G. Pacioni and A. Zambonelli (2014) Effects of soil tillage on Tuber magnatum development in natural truffières. Mycorrhiza 24: S79-S87.

Sourzat P. (2011) Black truffle cultivation and competing fungi. Proceedings of the 7th International Conference on Mushroom Biology and Mushroom Products (ICMBMP7). 516-528.

Splivallo R. and S. E. Ebeler (2015) Sulfur volatiles of microbial origin are key contributors to human-sensed truffle aroma. Applied Microbiology and Biotechnology 99:2583-2.

Splivallo R., A. Deveau, N. Valdez, N. Kirchhoff, P. Frey-Klett and P. Karlovsky (2015) Bacteria associated with truffle-fruiting bodies contribute to truffle aroma. Environmental Microbiology 17(8):26472660. doi:10.1111/1462-2920.12521

Stielow B. and W. Menzel (2010) Complete nucleotide sequence of TaV1, a novel totivirus isolated from a black truffle ascocarp (Tuber aestivum Vittad.). Archives of Virology 155:2075-2078

Stielow B., Z. Bratek, H. P. Klenk, S. Winter and W. Menzel (2012) A novel mitovirus from the hypogeous ectomycorrhizal fungus Tuber excavatum. Archives of Virology 157:787-790.

Stielow B., H. P. Klenk and W. Menzel (2011a) Complete genome sequence of the first endornavirus from the ascocarp of the ectomycorrhizal fungus Tuber aestivum Vittad. Archives of Virology 156:343-345.

Stielow B., H. P. Klenk, S. Winter and W. Menzel (2011b) A novel Tuber aestivum (Vittad.) mitovirus. Archives of Virology 156:1107-1110.

Trappe J. M. and A. Claridge (2010) The hidden life of truffles. Scientific American 302:78-84.

Turgeman T., Y. Sitrit, O. Danai, Y. Luzzati, A. Bustan, N. Roth Bejerano and V. Kagan-Zur (2012) Introduced Tuber aestivum replacing introduced Tuber melanosporum: a case study. Agroforestry Systems 84:337-343

Urban A., I. Neuner-Plattner, I. Krisai-Greilhuber and K. Haselwandter (2004) Molecular studies on terricolous microfungi reveal novel anamorphs of two Tuber species. Mycological Research 108:749-758.

Wang Y. (2012) Truffle cultivation in China. In: Edible Ectomycorrhizal Mushrooms. Current Knowledge and Future Prospects. A. Zambonelli and G. M. Bonito (eds.). Springer. Berlin, Germany. pp:227-240.

Zambonelli A. and M. lotti (2001) Effects of fungicides on Tuber borchii and Hebeloma sinapizans ectomycorrhizas. Mycological Research 105:611-614.

Zambonelli A. and R. Di Munno (1992) Indagine Sulla Possibilità di Diffusione dei Rimboschimenti con Specie Tartufigene: Aspetti Tecnico-colturali ed Economici. Ministero dell'Agricoltura e delle Foreste, Rome.356 pp.

Zambonelli A., M. lotti and C. Murat (2016) True Truffle (Tuber spp.) in the World. Soil Ecology, Systematics and Biochemistry. Soil Biology. Springer. Switzerland. $436 \mathrm{p}$.

Zambonelli A., M. Iotti and F. Piattoni (2012) Chinese Tuber aestivum sensu lato in Europe. The Open Mycology Journal 6:22-26.

Zambonelli A., M. Iotti and I. R. Hall (2015) Current status of truffle cultivation: recent results and future perspectives. Micol Ital 44:31-40.

Zambonelli A., M. Iotti, S. Boutahir, E. Lancellotti, C. Perini and G. Pacioni (2012) Ectomycorrhizal fungal communities of edible ectomycorrhizal mushrooms. In: Edible Ectomycorrhizal Mushrooms. Current Knowledge and Future Prospects. A. Zambonelli and G. M. Bonito Vol 34. Springer-Verlag. Berlin, Germany. pp:105-124.

Zampieri E., M. Chiapello, S. Daghino, P. Bonfante and A. Mello (2016) Soil metaproteomics reveals an inter-kingdom stress response to the presence of black truffles. Scientific Reports 6:25773 $10.1038 /$ srep25773.

Zampieri E., C. Murat, M. Cagnasso, P. Bonfante and A. Mello (2010) Soil analysis reveals the presence of an extended mycelial network in a Tuber magnatum truffle-ground. FEMS Microbiology Ecology 71:43-49. doi: 10.1111/j.1574-6941.2009.00783.x

Zeppa S., C. Guidi, A. Zambonelli, L. Potenza, L. Vallorani, R. Pierleoni, C. Sacconi and V. Stocchi (2002) Identification of putative genes involved in Tuber borchii fruit body development by mRNA Differential Display in agarose gel. Current Genetics 42:161-168.

Zhang J. P., P. G. Liu and J. Chen (2012) Tuber sinoaestivum sp. nov. an edible truffle from southwestern China. Mycotaxon 122:73-82. 
